\title{
Proportion of plankton biomass in particulate organic carbon in the northern Baltic Sea
}

\author{
Agneta Andersson ${ }^{1}$, Åsa Rudehäll ${ }^{2}$ \\ ${ }^{1}$ Department of Microbiology, University of Umeå, S-901 87 Umeå, Sweden \\ ${ }^{2}$ Umeå Marine Science Center, University of Umeá, Box 3124, S-903 04 Umeå, Sweden
}

\begin{abstract}
In many quantitative studies of the oceanic carbon cycle, measurements of particulate organic carbon (POC) in seawater are used for making budgets of planktonic food webs. In order to evaluate the seasonal changes of the constituents of POC in a temperate sea area, the proportion of autotrophic and heterotrophic plankton biomass in POC was measured for different seasons. At both a coastal and an offshore station in the northern Baltic Sea, POC was dominated by unidentified detritus material. Autotrophic microplankton dominated the plankton biomass in spring, and free-living heterotrophic bacteria in autumn and winter. The remaining plankton groups were of minor importance. The ratio of autotrophic plankton carbon to chlorophyll a (chl a) was determined by frequent sampling, and varied between 5 and $70\left(\mu \mathrm{g} \mathrm{l}^{-1} / \mu \mathrm{g} \mathrm{l}^{-1}\right)$, lowest in autumn-winter and highest in spring. Such variability makes it difficult to use constant conversion factors of chl a and POC to quantify plankton biomasses, and emphasizes the need for careful determination of conversion factors for specific environments and seasons.
\end{abstract}

\section{INTRODUCTION}

Relatively small changes in the oceanic carbon cycle may have large atmospheric consequences (JGOFS 1990). In recent years the interest in understanding the ocean carbon cycle has therefore increased. Measurements of biological rates are used in models describing, for example, the carbon flow in food webs (Hessen et al. 1990, Suttle et al. 1990), and/or the vertical transport and mineralisation of carbon (Smith et al. 1992). In such studies, measurements of particulate organic carbon (POC) in the sea are central, and the composition of POC has therefore been a subject of much interest (Smetacek \& Hendrikson 1979, Cho \& Azam 1990). However, the groups of organisms included in earlier studies have differed widely. Focus has been on large autotrophic plankton, disregarding the significance of heterotrophic plankton and cyanobacteria. Some recent papers though emphasise the importance of heterotrophic bacterial carbon contribution to POC (e.g. Cho \& Azam 1990).

The nutrient status of the sea generally influences the species composition of algae (e.g. Malone 1980); in oligotrophic waters, smaller cells dominate over larger, while the opposite prevails in eutrophic waters. This fact may explain the various results of the composition of POC in different seas. In some nutrient-rich seas, eukaryotic phytoplankton have been reported to account for over $80 \%$ of the POC (Hobson et al. 1973, Laws et al. 1988). In contrast though, Cho \& Azam (1990) found that in oligotrophic waters almost half the POC was composed of bacterial carbon. In many other studies, the non-living particulate carbon fraction has been shown to dominate (Valiela 1984).

In coastal environments, there is a large seasonal fluctuation in autotrophic plankton populations, with spring blooms of microplankton and summer blooms of nano- and picoplankton (Malone 1980). These fluctuations along with a varying river run-off give rise to a dynamic POC-pool in the water. The purpose of this study was to investigate the seasonal variation of microbial plankton carbon (PC) in relation to the POCpool in a coastal and shallow sea area in the northern Baltic Sea. All organisms ranging in size from small heterotrophic bacteria to relatively large autotrophic plankton and zooplankton were examined, with the aim of obtaining a complete picture. The ratio of autotrophic biomass to $\mathrm{chl}$ a was also determined. The 
northern Baltic Sea is a sea area influenced by allochthonous material. Since there is larger influence from rivers on nearshore localities, the investigation was conducted at both a nearshore and an offshore station.

\section{MATERIALS AND METHODS}

Study site. During 1991 and 1992 a coastal station (NB1: $19^{\circ} 48^{\circ} 07^{\prime \prime} \mathrm{E}, 63^{\circ} 31^{\prime} 00^{\prime \prime} \mathrm{N}$ ) and an offshore station (US5B: $19^{\circ} 58^{\prime} 05^{\prime \prime} \mathrm{E}, 62^{\circ} 35^{\prime} 00^{\prime \prime} \mathrm{N}$ ) in the Bothnian Sea, northern Baltic Sea (Fig. 1), were investigated. The water depths at the near- and offshore stations are 24 and $225 \mathrm{~m}$, respectively. The euphotic zone was determined to 0 to 20 and 0 to $14 \mathrm{~m}$ at the offshore and nearshore station, respectively.

Sample collection and analytical methods. POC, chl $a$ and PC (eukaryotic and prokaryotic plankton), were examined vertically in the euphotic zone. Sampling was performed 4 times at each station; during the early stage of the spring bloom (April), in summer (July), in autumn (October) and in winter (February). At the nearshore station, additional experiments were also carried out during the different stages of the spring bloom. Water (4 l) was collected with a bottle sampler (Hydro-Bios) from the surface to a depth of $20 \mathrm{~m}$ at $4 \mathrm{~m}$ intervals. The standard errors reported are based on mean values of the depth profiles and standard deviations of triplicate samples.

In addition to the vertical profiles, integrated samples for autotrophic plankton and chl a from the respective euphotic layer were taken every second week during the productive season (May to September) and every fourth week during other seasons, starting in February 1991. These samples were obtained by using plastic hoses, $25 \mathrm{~mm}$ diameter and $14 \mathrm{~m}$ (nearshore) and $20 \mathrm{~m}$ (offshore) long, respectively. This sampling technique gave similar results to the mean values calculated from discrete depths sampling (linear regression of chl $a_{\text {; }}$ slope $\left.=0.92, \mathrm{r}^{2}=0.99, \mathrm{n}=11\right)$.

Chl a. Seawater samples (500 to $1000 \mathrm{ml}$ ) were filtered onto a $47 \mathrm{~mm}, 0.45 \mu \mathrm{m}$ Millipore HA-filter. The chl a retained on the filter was extracted for $24 \mathrm{~h}$ in darkness at room temperature with $4 \mathrm{ml}$ of $95 \%$ ethanol and measured spectrophotometrically (750, 665 and $663 \mathrm{~nm}$ ) after centrifugation. Chl a concentration was then calculated according to Wintermans \& Demots (1965), using the absorption coefficient 83.41 $\mathrm{g}^{-1} \mathrm{~cm}^{-1}$.

POC. Seawater ( 300 to $500 \mathrm{ml}$ ) was filtered through a precombusted $\left(450^{\circ} \mathrm{C}\right.$ for 3 h) $18 \mathrm{~mm}$ glass fibre filter (Whatman GF/F). After filtration, the filters were dried at $40^{\circ} \mathrm{C}$ overnight and prior to analysis, they were cut into halves. On each sampling occasion, blank filters

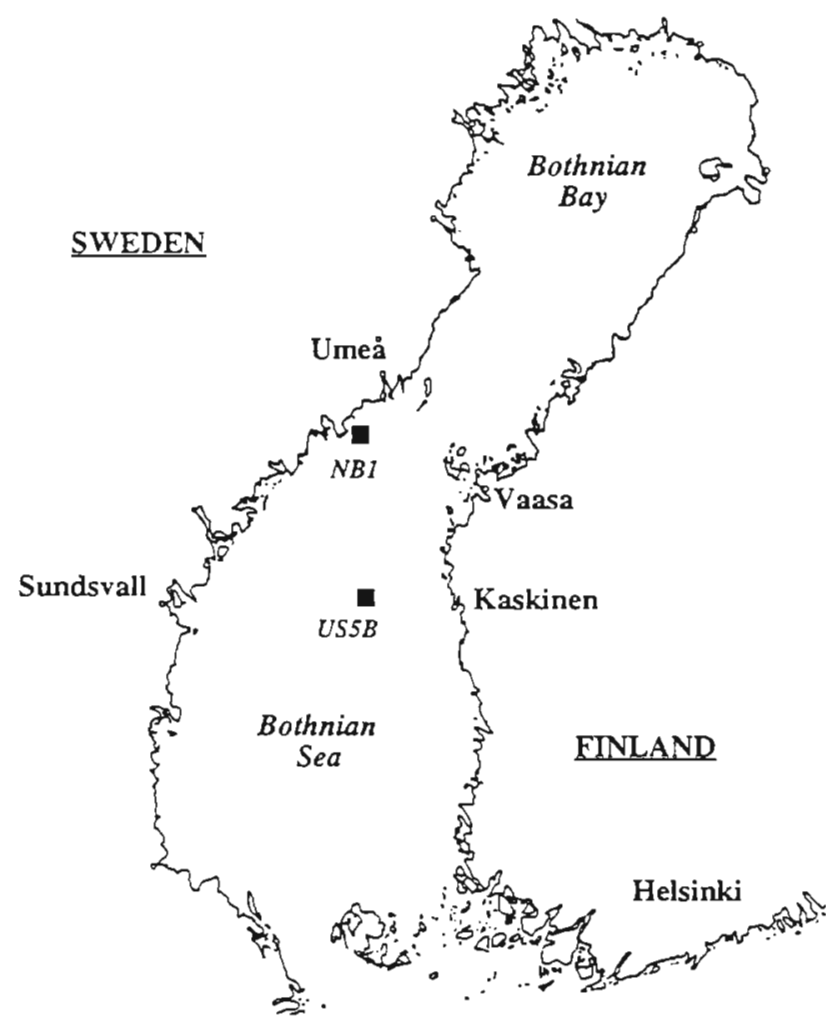

Fig. 1. Northern Baltic Sea showing the positions of the 2 sampling stations

were treated the same way. POC was determined with a Carlo Erba 1106 Elemental Analyzer. The measurements obtained from the 2 filter halves were added, the blank value was subtracted and POC per unit volume was calculated. The standard error for POC samples was about $2.4 \%$. The heterotrophic bacterial carbon $\left(H_{\text {pico }}\right)$ share of POC was corrected for a $30 \%$ filtration loss. All other identified organisms were retained on the GF/F filter and no further adjusting was needed.

Eukaryotic plankton. A subsample $(100 \mathrm{ml})$ was preserved in Lugol's solution ( $\mathrm{KI} 0.1 \mathrm{~g} \mathrm{ml}^{-1}, \mathrm{I}_{2} 0.05 \mathrm{~g} \mathrm{ml}^{-1}$ ) and acetic acid $\left(0.1 \mathrm{~g} \mathrm{ml}^{-1}\right)$ to a final concentration of $2 \%$. Each sample (10 to $50 \mathrm{ml}$ ) was settled overnight in a sedimentation chamber. Pigmented and nonpigmented plankton were classified, enumerated and measured using an inverted microscope. One-half of the sedimentation chamber $\left(265 \mathrm{~mm}^{2}\right)$ was scanned, counting plankton larger than $10 \mu \mathrm{m}$ at $250 \times$ magnification. For smaller cells $(<10 \mu \mathrm{m})$, a magnification of $500 \times$ was used and one diameter $\left(2.7 \mathrm{~mm}^{2}\right)$ of the chamber was scanned. At least 50 cells of the most common species and in total $>200$ cells sample ${ }^{-1}$ were counted. Cell volume was converted to cell carbon

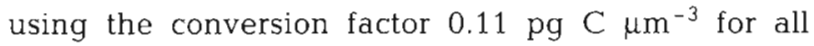
plankton, except for armoured dinoflagellates, where the corresponding factor was $0.13 \mathrm{pg} \mathrm{C} \mathrm{\mu m}^{-3}$ (Edler 
1979). The vacuole volume $(90 \%)$ was subtracted from the cell volume of diatoms. The standard error for estimation of the biomass of autotrophic microplankton, heterotrophic microplankton, autotrophic nanoplankton and heterotrophic nanoplankton was $10.9,9.3,7.5$ and $9.9 \%$, respectively.

Prokaryotic plankton. A subsample was fixed with formaldehyde, to a final concentration of $4 \%$. Cyanobacteria were quantified and measured with an epifluorescence microscope using a green excitation light with a $1200 \times$ magnification, after collecting 10 to $20 \mathrm{ml}$ on a $25 \mathrm{~mm}, 0.2 \mu \mathrm{m}$ polycarbonate MSI-filter. Heterotrophic bacteria were treated similarly: 3 to $15 \mathrm{ml}$ were filtered, stained with DAPI and counted in UV excitation light (Porter \& Feig 1980). For both autotrophic and heterotrophic bacteria, at least 15 microscopic fields per slide were scanned. The mean volume of heterotrophic bacteria was measured ( $>50$ cells slide $^{-1}$ ) by image analysis and determined to ca $0.18 \mu \mathrm{m}^{3}$. The conversion factor $0.11 \mathrm{pg} \mathrm{C} \mu \mathrm{m}^{-3}$ resulted in a cell carbon content of ca $20 \mathrm{fg} \mathrm{C}$ bacterium $^{-1}$ (for comparison, see Lee \& Fuhrman 1987). The standard error for enumeration of autotrophic and heterotrophic bacteria was ca 2.4 and $3.7 \%$, respectively.

\section{RESULTS}

The seasonal variation of autotrophic and heterotrophic plankton was investigated at a coastal and an offshore station in the Baltic Sea. The plankton were grouped according to size and pigmentation and showed the following composition. Microplankton $(10$ to $200 \mu \mathrm{m}$ ) were found to be a widespread heterogeneous group: e.g. dinoflagellates, diatoms, green algae $\left(A_{\text {micro }}\right)$, ciliates $\left(H_{\text {mucro }}\right)$ and others. The nano- plankton group ( 2 to $10 \mu \mathrm{m}$ ) contained pigmented ( $\left.A_{\text {nano }}\right)$ and nonpigmented $\left(H_{\text {nano }}\right)$ flagellates; the picoplankton group $(<2 \mu \mathrm{m})$ contained unicellular cyanobacteria $\left(A_{\text {pico }}\right)$ and heterotrophic bacteria $\left(H_{\text {pico }}\right)$.

At both stations, a marked seasonal variation of the plankton biomasses was observed (Table 1). The plankton biomass ranged from less than $10 \mu \mathrm{g} \mathrm{Cl}^{-1}$ in winter to ca $300 \mu \mathrm{g} \mathrm{Cl}^{-1}$ during the spring bloom maximum. The major part of the plankton biomass in spring was accounted for by dinoflagellates (55 to $62 \%$ ) and diatoms (11 to $24 \%$ ). Heterotrophic freeliving bacteria dominated in autumn and winter, contributing 50 to $60 \%$ of the total biomass. In summer, the biomasses of autotrophic microplankton and heterotrophic free-living bacteria were similar at the coastal station, each constituting ca $20 \%$ of the total biomass, while at the offshore station, heterotrophic bacteria dominated ( $43 \%$ of the biomass). Ciliates and other heterotrophic microplankton accounted for at most $18 \%$ of the plankton biomass in winter and only about $1 \%$ in summer. Their biomass maximum, $19 \mu \mathrm{g} \mathrm{Cl}^{-1}$, was found in May, at the same time as the spring bloom. Autotrophic pico- and nanoplankton reached their peaks in summer and autumn, contributing 10 to $20 \%$ of the biomass. At both stations, heterotrophic nanoplankton never exceeded $1 \%$ of the total plankton biomass.

\section{Composition of POC}

The highest concentration of POC $\left(668 \mu \mathrm{g} \mathrm{l}^{-1}\right)$ was found at the peak of the spring bloom at the coastal station. Minimum values of 99 and $160 \mu \mathrm{g} \mathrm{l^{-1 }}$ were detected in winter, offshore and nearshore, respectively. More POC was present at the nearshore station

Table 1. Seasonal variation of POC, detritus and plankton carbon (PC), offshore and nearshore in the northern Baltic Sea. Autotrophic $(A)$ and heterotrophic $(H)$ plankton carbon, as percentage of PC. Plankton are size-divided in pico-, nano- and microplankton

\begin{tabular}{|c|c|c|c|c|c|c|c|c|c|}
\hline Season & $\begin{array}{c}\text { POC } \\
\left(\mu g l^{-1}\right)\end{array}$ & $\begin{array}{l}\text { Detritus } \\
\left(\mu \mathrm{g} \mathrm{l}^{-1}\right)\end{array}$ & $\begin{array}{c}\mathrm{PC} \\
\left(\mu \mathrm{gl}^{-1}\right)\end{array}$ & $A_{\text {pico }}$ & $H_{\text {pico }}$ & $\begin{array}{c}A_{\text {nano }} \\
(\% \text { of } P C)\end{array}$ & $H_{\text {nano }}$ & $A_{\text {micro }}$ & $H_{\text {micro }}$ \\
\hline \multicolumn{10}{|l|}{ Ofishore } \\
\hline Spring & 267 & 168 & 99 & 1 & 6 & 2 & $<1$ & 88 & 3 \\
\hline Summer & 231 & 148 & 83 & 21 & 43 & 14 & $<1$ & 21 & 1 \\
\hline Autumn & 166 & 133 & 33 & 6 & 61 & 8 & 1 & 18 & 5 \\
\hline Winter & 99 & 91 & 8 & 3 & 49 & 5 & $<1$ & 24 & 18 \\
\hline \multicolumn{10}{|l|}{ Nearshore } \\
\hline Early spring & 248 & 191 & 57 & 1 & 6.9 & 2 & $<1$ & 80 & 10 \\
\hline Spring & 568 & 375 & 193 & 1 & 4.2 & 2 & $<1$ & 89 & 4 \\
\hline Spring bloom & 668 & 343 & 325 & 1 & 3.3 & 3 & $<1$ & 87 & 6 \\
\hline Summer & 340 & 282 & 58 & 8 & 36 & 19 & 1 & 36 & 1 \\
\hline Autumn & 181 & 151 & 30 & 16 & 54 & 6 & 1 & 19 & 3 \\
\hline Winter & 161 & 151 & 9 & 5 & 49 & 3.0 & $<1$ & 31 & 12 \\
\hline
\end{tabular}




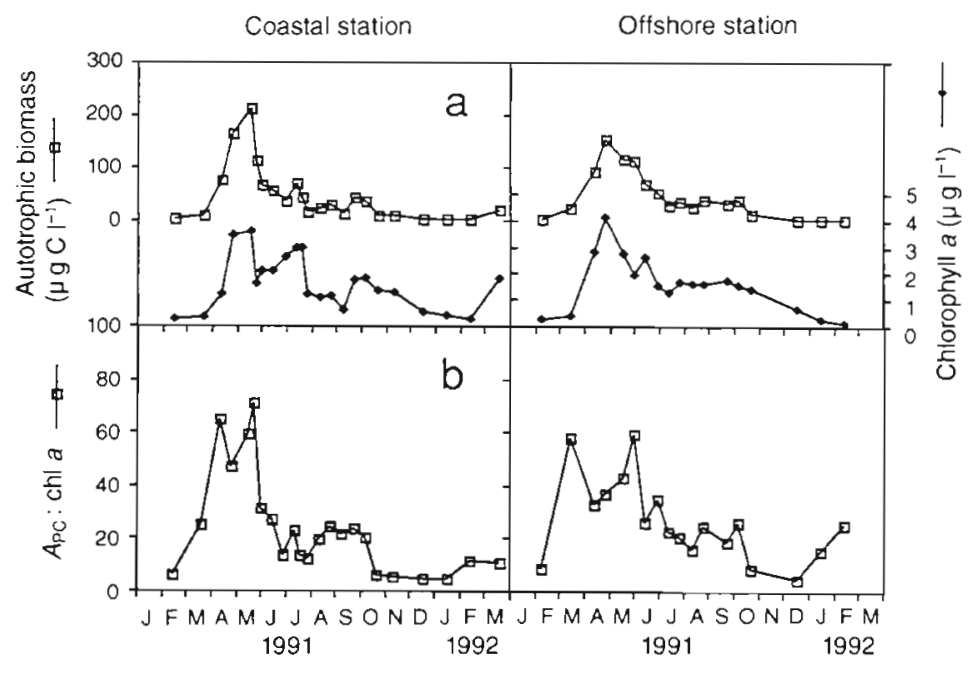

Fig. 2. (a) Variation of autotrophic plankton carbon $\left(A_{P C}\right)$ and chl $a$ and (b) the ratio of $A_{P C} / c h l$ a at the coastal and offshore stations during 1991 and 1992 of Chaetoceros spp. A marked reduction occurred in October and early winter with minimum ratios around 5. Starting in February, the ratio increased again. In the vertical profiles, the highest values were found at 4 to $8 \mathrm{~m}$. No significant differences were found between the near-and offshore stations.

\section{Vertical profiles}

The vertical distributions of autotrophic micro-, nano- and picoplankton at the nearshore and offshore stations were similar. Some typical profiles from the coastal station representing the 4 seasons are shown in Fig. $3 a, c$, e \& $g$. During the spring bloom, nanoplankton biomass was negligible compared to that of microplankton. In July, the distribution of autotrophic plankton was more or less homogeneous throughout the water column. Nano- and microplankton dominated in the upper half of the euphotic layer and each accounted for about $50 \%$ of the autotrophic biomass. At the lower half of the euphotic zone, there was a clear dominance of microplankton, mainly Chaetoceros spp. Picoplankton decreased slightly with depth. In autumn, the relative importance of picoplankton increased markedly, and together with nanoplankton contributed the same as microplankton to the total biomass. The lowest biomasses were detected in February for all 3 size-classes. Compared to autumn, the fraction of microplankton increased, while the proportion of smaller autotrophic plankton $(<10 \mu \mathrm{m})$ decreased.

The vertical profiles of POC show little or no covariation with those of chl a (Fig. $3 b, d, f \& h$ ), nor are they similar to the biomass profiles. Thus, changes in the autotrophic plankton biomass do not seem to reflect the POC values in the vertical profiles.

\section{DISCUSSION}

A marked seasonal variability of the constituents of the POC pool was observed. Autotrophic microplankton and free-living heterotrophic bacteria formed the bulk of 'living carbon'. $A_{\text {micro }}$ dominated the plankton biomass throughout spring and $H_{\text {pico }}$ during autumn and winter, while other plankton groups, e.g. nanoplankton, were of less importance. Previous productivity and biomass estimates indicate that phytoplankton and free-living heterotrophic bacterioplankton mediate most of the flow of carbon and associated nutrients from dissolved inorganic and organic pools to particulate organic pools, available to particle grazers
The ratio of autotrophic plankton carbon $\left(A_{\mathrm{PC}}\right)$ to $\mathrm{ch}$ a varied seasonally (Fig. 2). The highest $A_{\mathrm{PC}} / \mathrm{chl}$ a ratio was detected during the development of the spring bloom with a distinct peak after the spring bloom cul-

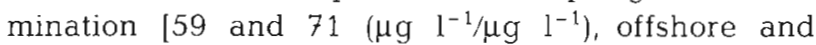
nearshore, respectively]. The ratio rapidly decreased in post-bloom periods, and was nearly constant (ca 20) during the summer and early autumn, with the exception of a small peak in July caused by a diatom bloom 

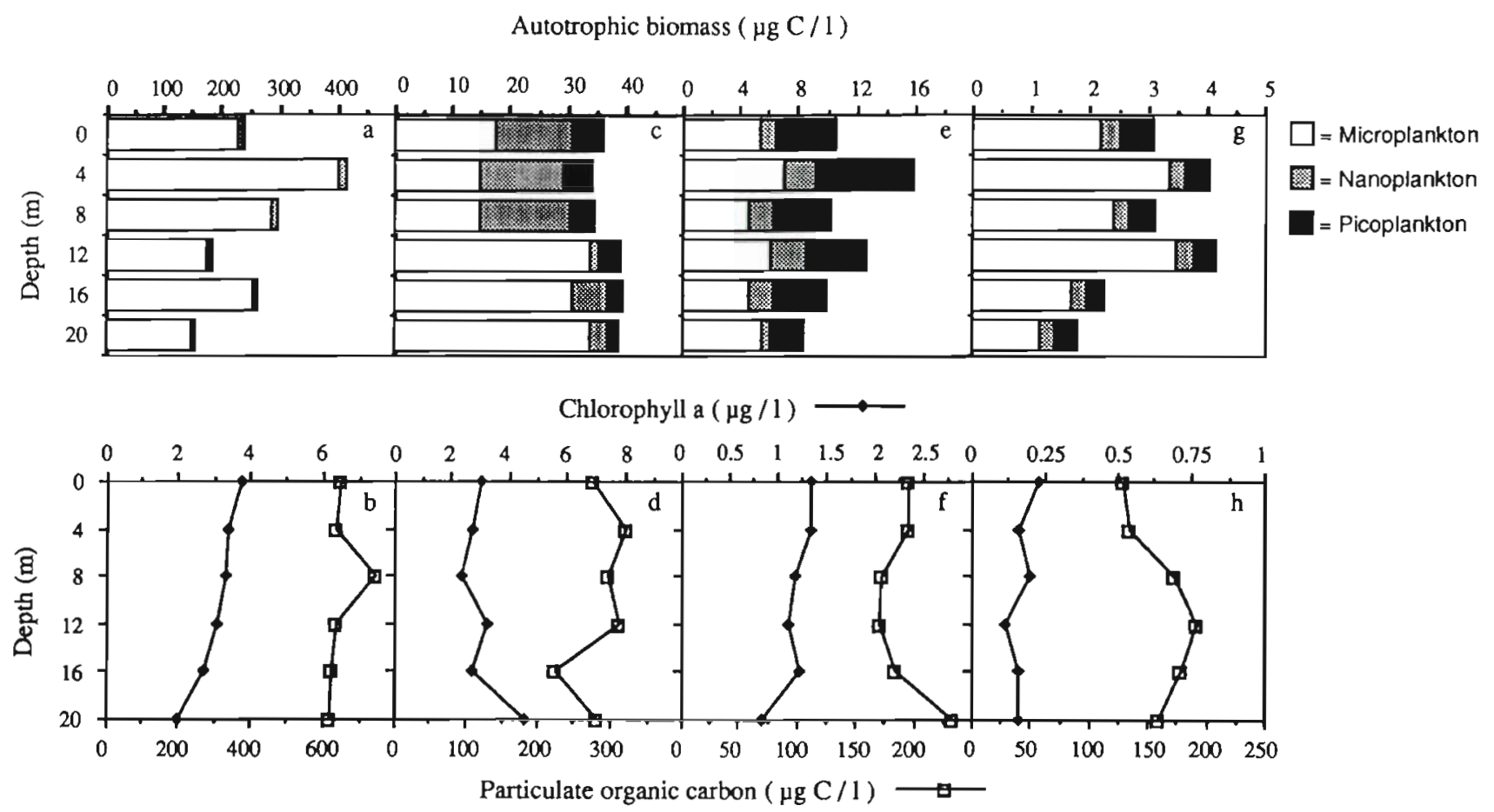

Fig. 3. Vertical distribution of autotrophic plankton carbon (micro-, nano- and picoplankton), chl a and POC at the coastal station during: $(a, b)$ spring bloom; $(c, d)$ summer; $(e, f)$ autumn; and $(g, h)$ winter

in the water column (Williams 1984). Thus, both groups represent the 'lowest' trophic levels in marine food webs. The base of a food chain, with several pyramidal trophic levels, may have relatively large biomass and/or rapid turnover time. Other groups of organisms, e.g. autotrophic and heterotrophic nanoplankton, represent intermediate trophic levels. They are carriers of organic material up through the food chain, and do not necessarily contribute largely to biomass

The spring phytoplankton bloom represents a pulsed source of organic carbon which is important to productivity and carbon flux in marine ecosystems (Laws et al. 1988). In agreement with this, the proportion of plankton biomass in POC was observed to be highest during this time of the year. Maximum POC values occurred during the spring bloom. This pattern corresponds to other coastal areas, whose spring maxima sometimes exceed $1000 \mathrm{Mg} \mathrm{l}^{-1}$ of POC (Holligan et al. 1984, Mayzaud et al. 1989). However, compared to oceanic concentrations (e.g. ca $20 \mu \mathrm{g} \mathrm{l}^{-1}$; Sharp et al. 1980), the POC concentrations turned out to be high (nearshore: 160 to $668 \mu \mathrm{g} \mathrm{l}^{-1}$ ). During autumn and winter, the particulate detritus made up as much as 85 to $95 \%$ of the POC. The dominance of non-living particles in the POC in this area may be an effect of high river input of allochtonous material and/or resuspended material (Forsgren \& Jansson 1992). The detrital part of POC was generally higher at the nearshore station than at the offshore station.

The plankton biomasses were calculated by microscopic analysis of plankton volumes. Recommended conversion factors were used to obtain cell carbon estimates. These compared well to chemical measurements from earlier studies: for equally sized cells of Thalassiosira spp., Gymnodinium spp. and Skeletonema costatum we estimated 1620,56 and 5 pg C cell $^{-1}$, while Chan (1980) and Strathmann (1967) obtained 1750,55 and $10 \mathrm{pg} \mathrm{C}$ cell $^{-1}$, respectively. The estimations of the biomass of different plankton groups have standard errors of ca $10 \%$ or less. Such variations do not affect the main conclusions of this study.

Besides estimating autotrophic biomass, chl a was also measured. Some of the environmental factors which are known to regulate the ratio of $A_{P C}$ to $\mathrm{chl}$ a are growth rate, light conditions and species composition (Table 2). These factors can be inter-dependent; the photosynthetic rate, and thus the growth rate, may be a function of nutrient status (Eppley 1972). Furthermore, the photosynthetic rate is also connected to the amount of irradiance. The degree of influence of each factor is not obvious. Moreover, the factors may not influence the $A_{\mathrm{PC}} / \mathrm{chl}$ a ratio levels consistently throughout the year. In this area, where there is almost $24 \mathrm{~h}$ of daylight in the summer, one would expect maximum ratios to occur during this time. In fact, this was 
Table 2. Factors suggested to influence the autotrophic plankton carbon $\left(A_{p C}\right)$ to chlorophyll a (chl a) ratio in seawater

\begin{tabular}{llcl|}
\hline Factor & & Apc $:$ chl a & Source \\
\hline Temperature & $\Downarrow$ & $\Uparrow$ & Eppley (1972) \\
Growth rate & $\Downarrow$ & $\Uparrow$ & Sakshaug et al. (1989) \\
Irradiance & $\Uparrow$ & $\Uparrow$ & Cullen (1982), Holligan et al. (1984) \\
Nutrients (phosphate, nitrogen, ammonium) $\Downarrow$ & $\Uparrow$ & $\Uparrow$ & Tett et al. (1975), Sakshaug et al. (1989) \\
No. of Dinophyceae & $\Uparrow$ & $\Uparrow$ & Chan (1980) \\
Cell size of eukaryotes & $\Uparrow$ & $\Uparrow$ & Malone (1980), Furuya (1990) \\
\hline
\end{tabular}

not the case at either of the stations for this study (Fig. 2b). In accordance with this theory though, minimum ratios occurred simultaneously with minimum irradiance between October and December. Thus, the high $A_{P C} /$ chl a ratio in spring was a result of the bloom mainly consisting of dinoflagellates and other large eukaryotes (Chan 1980, Malone 1980, Furya 1990). The peak of $A_{P C} / c h l$ a appearing immediately after the spring bloom culmination would most likely be due to stress caused by nutrient depletion (Jonge 1980). The $A_{\mathrm{PC}} / \mathrm{chl}$ a ratio also varied somewhat vertically in the water column because of differences in species composition, light and nutrient conditions. Thus, it is not obvious that the carbon biomass maxima coincides with the chl a maxima.

The values of $A_{\mathrm{PC}} / \mathrm{chl}$ a presented here are mainly within the range of earlier published values (Hobson et al. 1973, Bodungen et al. 1975), except for the low values in winter. In the attempts to find conversion factors for estimating plankton carbon from chemical measurements of chl $a$, we are encouraged by the fact that relatively few autotrophic plankton species are dominant in the northern Baltic Sea. In spring bloom situations, for example, when 1 or 2 groups dominate the algal community, acceptable estimations should be possible (Riemann et al. 1982). This study covers 1 yr (1991) and 2 separate stations, and similar fluctuations of $A_{\mathrm{PC}} / \mathrm{chl}$ a were found at both stations. Furthermore, the variations were found to be repeated during 1992. The ratio after the spring bloom culmination, in summer and autumn was 80,17 and 4 respectively, at the nearshore station. From these results it is clear that the $A_{\mathrm{pC}} / \mathrm{chl}$ a ratio varies with season in the studied area. Similar seasonal variations in the $A_{\mathrm{pC}} / \mathrm{chl}$ a ratio may also occur in other temperate seas.

The data presented here stress the seasonal variability of the constituents of the POC pool and ratio of autotrophic biomass and chl a. Such fluctuations make it difficult to use constant conversion factors for estimating pools of biomasses from chl a or POC measurements, except for given environments and seasons. The use of a fixed conversion factor of 50, for example, to abtain phytoplankton carbon from chl a, may imply an over-estimation of the phytoplankton carbon by a factor of ca 10. Thus in quantitative studies, like in modelling of the carbon flow in food webs, we suggest that careful determination of the conversion factors should be made on a seasonal basis.

Acknowledgements. This work was supported by grants from the Swedish National Science Research Council (No. 7615016-8). We thank Dr Erik Lundberg and Mr Carl-Henrik Stangenberg for chemical analyses, and Prof. and Mrs Blackburn for critical comments and linguistic corrections on drafts of this manuscript. The laboratory facilities of the Umea Marine Sciences Center are gratefully acknowledged.

\section{LITERATURE CITED}

Bodungen, B. v., Bröckel, K. v., Smetacek, V., Zeitzschel, B. (1975). Ecological studies on the plankton in the Kiel Bight. I. Phytoplankton. Merentutkimusalaitoksen Julk. Havsforskningsinst. Skr. 239: 179-186

Chan, A. T. (1980). Comparative physiological study of marine diatoms and dinoflagellates in relation to irradiance and cell size. II. Relationship between photosynthesis, growth, and carbon/chlorophyll a ratio. J. Phycol. 16: $428-432$

Cho, B. C., Azam, F. (1990). Biogeochemical significance of bacterial biomass in the ocean's euphotic zone. Mar. Ecol. Prog. Ser. 63: 253-259

Cullen, J. J. (1982). The deep chlorophyll maximum: comparing vertical profiles of chlorophyll a. Can. J. Fish. Aquat. Sci. 39: 791-803

Edler, L. (1979). Recommendations on methods for marine biological studies in the Baltic Sea. The Baltic Marine Biologists (BMB) Publ. No. 5, Malmö

Eppley, R. W. (1972). Temperature and phytoplankton growth in the sea. Fish. Bull. U.S. 4: 1063-1085

Forsgren, G., Jansson, M. (1992). The turnover of rivertransported iron, phosphorus and organic carbon in the Öre Estuary, N Sweden. Hydrobiologia 235/236: 585-596

Furuya, K. (1990). Subsurface chlorophyll maximum in the tropical and subtropical western Pacific Ocean: vertical profiles of phytoplankton biomass and its relationship with chlorophyll a and particulate organic carbon. Mar. Biol. 107: 529-539

Hessen, D. O., Andersen, T., Lyche, A. (1990). Carbon metabolism in a humic lake: pool sizes and cycling through zooplankton. Limnol. Oceanogr. 35: 84-99

Hobson, L. A., Menzel, D. W., Barber, R. T (1973). Primary productivity and sizes of pools of organic carbon in the mixed layer of the ocean. Mar Biol. 19: 298-306

Holligan, P. M., Harris, R. P., Newell, R. C., Harbour, D. S., Head, R. N., Linley, E. A. S., Lucas, M. I., Tranter, P. R. G., Weekley, C. M. (1984). Vertical distribution and partition- 
ing of organic carbon in mixed, frontal and stratified waters of the English Channel. Mar. Ecol. Prog. Ser. 14: $111-127$

JGOFS (1990). A study of global change. Joint Global Ocean Flux Study, Report No. 12, Stockholm

Jonge, V. N. de (1980). Fluctuations in the organic carbon to chlorophyll a ratios for estuarine benthic diatom populations. Mar. Ecol. Prog. Ser. 2: 345-353

Laws, E. A., Bienfang, P. K., Ziemann, D. A., Conquest, L. D. (1988). Phytoplankton population dynamics and the fate of production during the spring bloom in Akue Bay, Alaska. Limnol. Oceanogr. 33: 57-65

Lee, S., Fuhrman, J. A. (1987). Relationship between biovolume and biomass of naturally derived marine bacterioplankton. Appl, environ. Microbiol. 53: 1298-1303

Malone, T. C. (1980). Algal size. In: Morris, I. (ed.) The physiological ecology of phytoplankton. Univ. of California Press, Berkeley, p. 433-461

Mayzaud, P., Chanut, J. P., Ackman, R. G. (1989). Seasonal changes of the biochemical composition of marine particulate matter with special reference to fatty acids and sterols. Mar. Ecol. Prog. Ser. 56: 189-204

Porter, K. G., Feig, Y. S. (1980). The use of DAPI for identifying and counting aquatic microflora. Limnol. Oceanogr. 31: $1010-1021$

Riemann, B., Søndergaard, M. Schierup, H. H., Bosselmann, S., Christensen, G., Hansen, J., Nielsen, B. (1982), Carbon metabolism during a spring diatom bloom in the eutrophic lake Mossø. Int. Rev. ges. Hydrobiol. 67: 145-185

Sakshaug, E., Andresen, K., Kiefer, D. A. (1989). A steadystate description of growth and light absorption in the marine planktonic diatom Skeletonema costatum. Limnol Oceanogr. 34: 198-205

This article was submitted to the editor
Sharp, J. H., Perry, M. J., Renger, E. H., Eppley, R. W. (1980). Phytoplankton rate processes in the oligotrophic waters of the central North Pacific Ocean. J Plankton Res. 2: $335-353$

Smetacek, V., Hendrikson, P. (1979). Composition of particulate organic matter in Kiel Bight in relation to phytoplankton succession. Oceanol. Acta 2: 287-298

Smith, K. L. Jr, Baldwin, R. J., Williams, P. M. (1992). Reconciling particulate organic carbon flux and sediment community oxygen consumption in the deep North Pacific. Nature 359: 313-316

Strathmann, R. R. (1967). Estimating the organic carbon content of phytoplankton from cell volume or plasma volume. Limnol. Oceanogr. 12: 411-418

Suttle, C. A., Fuhrman, J A., Capone, D. G. ( 1990). Rapid ammonium cycling and concentration-dependent partitioning of ammonium and phosphate: implications for transfer in planktonic communities. Limnol. Oceanogr. 35 : 424-433

Tett, P., Cottrell, J. C., Trew, D. O., Wood, B. J. B. (1975). Phosphorus quota and the chlorophyll:carbon ratio in marine phytoplankton. Limnol. Oceanogr. 20: 587-603

Valiela, I. (1984). Marine ecological processes. Springer, New York

Williams, P. J. leB. (1984). Bacterial production in marine food chains: Emperor's new suit of clothes. In: Fasham, M. J. R. (ed.) Flows of energy and materials in marine ecosystems: theory and practice. NATO Conf. Ser. 4. Mar. Sci. Vol. 13 Plenum, New York, p. 271-299

Wintermans, J. F. G. M., Demots, A. (1965). Spectrophotometric characteristics of chlorophylls $a$ and $b$ and their phaeophytins in ethanol. Biochim. Biophys. Acta 109: $448-453$

Manuscript first received: June 17, 1992

Revised version accepted. February 19, 1993 